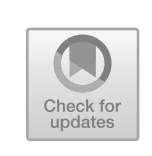

\title{
5 \\ Shared Mobility: A Reflection on Sharing Economy Initiatives in European Transportation Sectors
}

\author{
Agnieszka Lukasiewicz, Venere Stefania Sanna, \\ Vera Lúcia Alves Pereira Diogo, and Anikó Bernát
}

\section{Introduction}

Mobility is an inherent component of human life, and thus there is no need to underline its importance. Sharing mobility systems have become a common feature of the modern urban landscape in many cities worldwide (Shaheen et al. 2015), providing residents and visitors with a new mode of transportation. Such a substantial change in people's thinking and behaviours resulted in triggering a mobility ecosystem which is favouring a model more focused on 'accesses' to a means of transportation rather than ownership. This attitude has a great influence on mobility pattern changing, especially in urban space,

\footnotetext{
A. Lukasiewicz ( $\square)$

Management Systems and Telematics Division, Road and Bridge Research Institute, Warsaw, Poland e-mail: alukas@ibdim.edu.pl

V. S. Sanna

Centre for Politics and International Studies (CeSPI), Department of MEMOTEF, Sapienza University, Rome, Italy 
where sharing can assume a number of forms: (1) purchase a servicepay for a ride (ride-sharing); (2) exchange a service (car-pooling); (3) renting - a vehicle can be rented rather than purchased (car-sharing); (4) lending - a vehicle can be borrowed or loaned (car-sharing); (5) subscribing - people can become members of a car-sharing scheme (carsharing); and (6) donating-people can give free rides in their vehicle (car-pooling) (Standing et al. 2019).

The concept of shared-use mobility systems dates back to the 1960 s in Europe. The idea has spread over the years, contributing both to a substantial reduction in the individual use of private vehicles and by integrating itself into urban public transportation systems. Some European public entities also have experience with a wide range of public-private partnership arrangements in this sphere. Various definitions of shared mobility can be found in the literature. Machado et al. (2018) widely define shared mobility as trip alternatives aiming to maximise the utilisation of the mobility resources that society can pragmatically afford, disconnecting their usage from ownership. Thus, shared mobility is the short-term access to shared vehicles related to the user's needs and convenience. The majority of authors agree that shared mobility is characterised by the sharing of a vehicle, therefore 'access' instead of ownership, and the use of technology to connect users and providers (Crozet et al. 2019; Santos 2018). Such access is typically facilitated by a digital platform.

This chapter adopts the definition suggested by Shaheen and coauthors (2015), who affirm that shared mobility is 'the shared use of a vehicle, bicycle, or another mode-enabling users to gain short-term access to transportation modes on an 'as-needed' basis. New forms of

\section{L. A. P. Diogo}

Department Polytechnic Institute of Porto, iNED Center for Research and Innovation On Education, Porto, Portugal e-mail: veradiogo@ese.ipp.pt

\section{A. Bernát}

TÁRKI Social Research Institute, Budapest, Hungary e-mail: bernat@tarki.hu 
'mobility 2.0' range from the more traditional bike and car, scooter, van and on-demand ride services-used for both person transport and for goods and urban freight deliveries - to more innovative solutions such as e-scooter services and car park sharing. The shared mobility sector is part of the wider 'collaborative and sharing economy' defined in the European agenda (European Commission 2016). The question arises how the sharing and collaborative economy and, in particular, the shared mobility systems influence the path towards sustainable development.

In 2016 the CIVITAS Forum Network published a Policy Note in which the most relevant impacts that shared mobility services have on cities have been identified and related to the three main pillars of sustainability: environmental, social and economic. Moreover, the study claims that there is an increase in mobility services coordination, leading to the generation of a 'mobility ecosystem', which means that mobility is considered as a single, consistent service, rather than a series of different and separate set of services (CIVITAS 2016). That indicates its relationship with the concept of 'mobility as a service' (MaaS).

Nevertheless, sustainability in the transport sector is hard to achieve because different stakeholders, characterised by contrasting interests, are involved-and this is particularly the case of some sharing services such as Uber, which caused a number of conflicts among stakeholders and therefore raised criticisms. Moreover, the infrastructure for different, and new forms of transport, such as electric scooters, is limited, and that can generate additional competition.

Certainly, 2020 will be remembered as the year of the outbreak of the COVID-19 virus in Europe. Because of the risk of infection, the need for social distance, and lockdown, the pandemic has triggered a shift in users' priorities in relation to mobility. A change in travel behaviour and the use of shared mobility was observed, with travellers inclined to put more trust in private transport. Inevitably, the changeability and uncertainty of the current situation suggest there will be a further evolution of mobility habits, including rethinking the use of shared mobility altogether. As a matter of fact, users that want to avoid COVID-19 transmission might eventually come to view ride-sharing as a good alternative to more congested forms of mobility that make social distance difficult, such as public transportation (Andersson et al. 2020). 


\section{Applying the Stakeholder Approach to Shared Mobility}

The World Commission on Environment and Development of the United Nations (1987) set the foundation for the sustainability concept by stating that, in its broadest sense, a sustainable development strategy aims at promoting harmony among human beings and between humanity and nature, entailing that for sustainability, society and environment are crucial elements, in addition to the economy. Building on this, a first sustainability concept was developed by Elkington (1999) as the 'triple bottom line' or 'Triple-P (People, Planet, Profit)' model, regarding sustainability as the balance between economic, social, and environmental issues.

In 2015, all the member states of the United Nations approved the 2030 Agenda for Sustainable Development. This broad action program aims to end poverty, protect the planet and ensure prosperity for all, and includes 17 Sustainable Development Goals (SDGs), for a total of 169 'targets' or milestones to be met by 2030 with the intention of leaving no one behind (UNPF 2015). Sustainable transport is a theme that crosses numerous development objectives; it is a prerequisite to progress in realising the promise of the Agenda and is fundamental to achieve those targets related, for example, to healthy living, air quality and the reduction of air pollution. Transport is therefore causally linked with Goals such as number 3 (health and well-being), 9 (industry, innovation and infrastructures), 11 (sustainable cities and communities), and 13 (fight against climate change). Of big significance is the shift from a focus on providing mobility based on individual motorised transport and improved traffic speed to the idea of access to transport, prioritising people and their quality of life, with strong attention to safety and social equity (United Nations 2016). According to the HighLevel Advisory Group created by the UN, sustainable transport is 'the provision of services and infrastructure for the mobility of people and goods-economic and social development to benefit today's and future generations - in a manner that is safe, affordable, accessible, efficient 
and resilient, while minimising carbon and other emissions and environmental impacts'. As Litman (2021) states, common sustainable transport objectives include:

1. Improved transport system diversity. This generally means improving walking, cycling, ride-sharing, public transportation, car-sharing, telework and local delivery services, and creating more walkable and transit-oriented communities.

2. Smart growth of land use development. This includes land-use policies that create more compact, mixed, connected, multi-modal development and provide more affordable housing in accessible, multi-modal locations.

3. Energy conservation and emission reductions. This may include more fuel-efficient vehicles, shifts to alternative fuels, and reductions in total motor vehicle travel. This includes improving the quality of energy-efficient modes, including walking, cycling, ride-sharing, public transit and telework, and increasing land use accessibility.

4. Efficient transport pricing. This includes more cost-based pricing of roads, parking, insurance, fuel, and vehicles.

Demographic trends-including the rising number of older people, as well as the young generation, which increasingly make use of, and are familiar with, the internet, mobile devices and social media-have consequences for transport (Mitrović Dankulov et al. 2020). In particular, accessibility and proximity are crucial for older people, while younger generations are driving trends, including the one favouring the sharing economy. Nevertheless, those trends vary according to the geographical location and their level of development (Crozet et al. 2019). Such attitudes towards sharing and on-demand transport, joining public transport services and shared transport can allow, especially in cities, to move away from the conventional models of car-centric development.

Shared transport is characterised by the involvement of many different stakeholders and complex relationships. Stakeholder theory was first described by R. Edward Freeman (1984) in his landmark book Strategic Management: A Stakeholder Approach. Freeman suggests that shareholders are merely one of many stakeholder groups in a company. According 
to the theory, the stakeholders' setting includes anyone invested and involved in or affected by the company: employees, environmentalists near the company's plants, vendors, governmental agencies and more. Presented theory suggests that a company's real success lies in satisfying all its stakeholders, not just those who might profit from its stock. So, it is about creating value for stakeholders (Freeman et al. 2010). Similarly, sustainable transport should create good value for many of the present, as well as the future stakeholders. In the description of sustainable development included in Agenda 2030, prosperity and attention for all stakeholders are assumed. Those who are affected and who affect - thus all involved in the process of creating new business models in shared mobility-should be satisfied, which often is not possible. In addition, different views and aims make stakeholders take opposite stances. It can be observed in the sharing economy transport sector. Additionally, new emerging means of transport such as electric scooters joining already crowded streets, where the present infrastructure is not enough for the existing traffic, can create conflict between different kinds of users. Different kinds of conflicts are distinguished; however, while taking into consideration shared mobility, the conflict concentrates on the competition between groups within society over limited resources, as well as different interests. There are opposite groups, such as in the case of Uber - taxi drivers that do not accept inequalities and their interests are in opposition. Conflict can take different forms, from hidden antagonism to open fights.

\section{The European Mobility Ecosystem in Data}

According to the European Commission (2019, p. 3), 'transport's activity across Europe is high and set to continue growing, estimates suggest that passenger transport will increase by $42 \%$ by 2050 , and freight transport by $60 \%$ '. In particular, over the past few decades, passenger transport has grown rapidly, and it is expected to follow a similar trend for the future (Eurostat 2020a, b). This unbalanced and rapid growth has resulted in a multitude of effects on people and the environment, including traffic congestion, pollution, and health-related issues, which in the absence of 
a radical shift towards more sustainable (and maybe shared) means of transportation, will worsen even further in the immediate future.

In order to assess the possible contribution of shared mobility to the transition towards a more sustainable European mobility ecosystem, it is relevant to understand which sectors contribute the most to the current modal split scenario. Considering the EU-28 modal split by mode (Table 5.1), data shows that overall, the car is the most used mode of transportation, accommodating more than $70 \%$ of the total trips in 2017. From a historical perspective (last row of Table 5.1), air transport $(72.3 \%)$ is the sector that grew the most over the last 23 years. Public transport experienced a significant increase for tram and metro $(14.3 \%)$ and railway $(6.2 \%)$, while sea transport $(-33.3 \%)$ and bus and coach $(-23.7 \%)$ have decreased. As a result, even though the share of the tram, metro and railway (15.8\% in 2017) transport is growing over time, public transport is still perceived to be a poor alternative to car use (70.9\% in 2017).

In a more detailed way (Table 5.2), in 2017, data about a modal split of passenger transport on land by country shows that overall, the EU-28 passenger relies for $80.9 \%$ on cars, while public transport counts for less than $20 \%$ in total (with the following shares: $11.7 \%$ buses and coaches,

Table 5.1 EU-28 Performance of modal split by mode (\%)

\begin{tabular}{|c|c|c|c|c|c|c|c|}
\hline Year & $\begin{array}{l}\text { Passenger } \\
\text { cars }\end{array}$ & P2W & $\begin{array}{l}\text { Bus } \\
\text { and } \\
\text { Coach }\end{array}$ & Railway & $\begin{array}{l}\text { Tram } \\
\text { and } \\
\text { Metro }\end{array}$ & Air & Sea \\
\hline 1995 & 73.3 & 2.1 & 9.7 & 6.4 & 1.4 & 6.5 & 0.6 \\
\hline 2000 & 72.9 & 1.8 & 9.2 & 6.4 & 1.4 & 7.8 & 0.5 \\
\hline 2005 & 72.7 & 1.9 & 8.7 & 6.2 & 1.4 & 8.5 & 0.5 \\
\hline 2010 & 72.9 & 1.9 & 8.3 & 6.5 & 1.5 & 8.4 & 0.4 \\
\hline 2015 & 71.6 & 1.9 & 8.0 & 6.8 & 1.6 & 9.7 & 0.3 \\
\hline 2017 & 70.9 & 1.8 & 7.4 & 6.8 & 1.6 & 11.2 & 0.4 \\
\hline $\begin{array}{c}\text { Variation } \\
1995- \\
2017\end{array}$ & $-3.8 \%$ & $-14.3 \%$ & $-23.7 \%$ & $6.2 \%$ & $14.3 \%$ & $72.3 \%$ & $-33.3 \%$ \\
\hline
\end{tabular}

Notes Modal split by mode: indicator defined as the percentage share of each mode of transport in total inland transport

Air and Sea only domestic and intra EU-28 transport; provisional estimates P2W powered two-wheelers

Source Own elaboration based on (EC 2019) 
Table 5.2 EU-28 modal split of passenger transport on land (2017) by country

\begin{tabular}{lllll}
\hline & Passenger cars & Buses and coaches & Railways & Trams and metro \\
\hline EU-28 & 80.9 & 11.7 & 5.7 & $\mathbf{1 . 7}$ \\
BE & 81.1 & 10.1 & 7.7 & 1.1 \\
BG & 81.5 & 14.9 & 2.0 & 1.5 \\
CZ & 66.2 & 15.7 & 8.4 & 9.7 \\
DK & 81.2 & 9.9 & 8.5 & 0.5 \\
DE & 84.2 & 5.6 & 8.6 & 1.5 \\
EE & 79.9 & 17.2 & 2.2 & 0.7 \\
IE & 82.3 & 14.3 & 3.1 & 0.3 \\
EL & 81.4 & 16.4 & 0.9 & 1.3 \\
ES & 83.5 & 7.7 & 6.9 & 1.9 \\
FR & 81.0 & 6.2 & 10.9 & 1.8 \\
HR & 82.7 & 13.1 & 2.3 & 1.9 \\
IT & 82.0 & 11.4 & 5.9 & 0.7 \\
CY & 81.0 & 19.0 & - & - \\
LV & 83.8 & 12.1 & 3.3 & 0.7 \\
LT & 91.1 & 8.0 & 0.9 & - \\
LU & 82.9 & 12.4 & 4.7 & - \\
HU & 67.6 & 20.4 & 8.6 & 3.4 \\
MT & 82.5 & 17.5 & - & - \\
NL & 85.3 & 2.8 & 11.3 & 0.5 \\
AT & 72.7 & 9.7 & 11.2 & 6.4 \\
PL & 77.2 & 13.5 & 7.6 & 1.6 \\
PT & 87.6 & 7.0 & 4.3 & 1.1 \\
RO & 75.4 & 14.1 & 4.4 & 6.1 \\
SI & 86.5 & 11.7 & 1.8 & - \\
SK & 73.8 & 15.6 & 9.9 & 0.7 \\
FI & 83.6 & 10.3 & 5.4 & 0.7 \\
SE & 81.7 & 7.0 & 9.4 & 1.9 \\
UK & 84.5 & 5.0 & 8.7 & 1.8 \\
\hline SOUre & & & &
\end{tabular}

Source Own elaboration based on (EC 2019)

$5.7 \%$ railways, $1.7 \%$ trams and metro). There are no countries where means of transportation other than cars count for the majority of the modal shift-share. Nevertheless, there are a few countries which show a better distribution among the analysed means, such as Hungary $(67.6 \%$ passenger cars, $20.4 \%$ buses and coaches, $8.6 \%$ railways, and $3.4 \%$ trams and metro) and the Czech Republic (66.2\% passenger cars, $15.7 \%$ buses and coaches, $8.4 \%$ railways and $9.7 \%$ trams and metro). 
Overall, these figures reveal that the dependence on the car has accelerated dramatically in most European cities between 1995 and 2017, whereas public transport has remained at very low levels, with some modest success stories (e.g., Hungary, Malta, Estonia, Slovakia for bus and coaches; the Netherlands, Austria, and France for railways and the Czech Republic, Austria; and Romania for trams and metro). Clearly, car dependence has a series of implications for the future sustainability of cities, and shared mobility can play a key role in a transition towards a more sustainable European mobility ecosystem.

The access to actual figures of shared mobility services is still limited and what can be presented in this chapter represents a non-exhaustive overview. Nevertheless, some data about the principal sharing schemes available in Europe can help to understand this fast-evolving sector and might contribute to highlight possible synergies with other transport modes-especially with public transport.

\section{Car-Based Sharing Models: Evolution and Recent Trends}

The car-based sharing landscape in Europe is evolving rapidly. Systems can vary from: vehicles available for self-drive (e.g., public such as Car Sharing Rome, or private such as Share Now); services provided by private car owners, who provide for-hire rides such as ride-hailing - to parallel a taxi service (e.g., Uber or Lyft), or ride-sharing-individuals offering to share their vehicle on usually longer journeys (e.g., $\mathrm{BlaBlaCar}$ ); to car-pooling where associates and employees of individual companies can select a car from a fleet of vehicles as required.

About services where people 'pay for a ride' such as Uber or $\mathrm{BlaBlaCar}$ - stressing that the first one is more similar to taxi servicethe landscape of these services in Europe is very varied. In some countries such as Italy, Germany, Hungary, France, Finland, and the Netherlands, the strict regulation in the taxi industry makes it difficult for concepts such as Uber to penetrate while ride-sharing is allowed. In countries such as the United Kingdom, apps, e.g., Uber and Gett, can operate 
because they have been properly regulated, and BlaBlaCar is becoming increasingly popular (Schiller et al. 2017).

About the use of car-sharing, the EU-funded project Shared mobility opportunities And challenges foR European citieS (STARS) in 2018 reported and assessed different aspects of the majority of European carsharing services (about 90\% of the total), with 186 analysed car-sharing services spread over 25 countries (Rodenbach et al. 2018). According to this research, the most diverse selection of car-sharing services is found in Germany - with 155 available at the time of publication. They found that Belgium, France, Italy, the Netherlands and the UK also offered a large number of car-sharing services. Furthermore, some of the schemes are cross-border, operating in a number of national territories. The researchers identified Share Now, Zipcar, Communauto, Snappcar and Carmigo as enjoying a more dominant market position due to their more 'international approach' (Rodenbach et al. 2018).

In the past few years, car-sharing has gained popularity due to several positive factors, such as reduced travel costs, traffic congestion and emissions. Before the pandemic, almost 1000 cities worldwide have offered car-sharing services (Movmi 2019). However, the COVID-19 outbreak's impact on the sector is huge, and 'the car-sharing market is estimated to lose its share by 50-60\% during 2020' (MarketsandMarkets Research Private Ltd. 2020). Even though evidence-based research on the impact of COVID-19 measures on a modal share of private and public transport are still scarce (Bucsky 2020), some study argues that private car usage increased dramatically during the pandemic while car-sharing lost its shared as a 'result of the WHO recommendations to maintain social distancing and avoid sharing the same space with multiple people' (Articonf 2020).

\section{Bike-Sharing: A Fast-Growing Sector}

Bike-sharing systems (BSS) have experienced a significant evolution over time. From a technological point of view, BSS available in Europe today belong mainly to (i) the third generation systems, where bicycles can be borrowed or rented from an automated station or 'docking stations' (bike 
racks) that lock the vehicle and only release it by computer control (in this system the bike can be returned at any station belonging to the same system) and (ii) the fourth-generation systems where: free-floating bikes (dockless bikes) are available on-demand using mobile phone apps and Global Positioning System (GPS) technologies.

Due to the rapid changes in BSS systems, and the dynamic of the market providers, it is almost impossible to quantify the number of bikes available in Europe. There are some estimates based on a variety of sources that cannot be considered definitive numbers. A Bike Share World Map has been made available by Google (Meddin et al. 2020) in order to localise bike-sharing schemes all over the world. At the date of publishing, according to Wikipedia, Europe counts 190,000 bicycles available for sharing (Wikipedia 2020).

Countries such as Spain, France, the United Kingdom and Italy have the largest number of such schemes, which are all but absent in 'cycling countries' such as the Netherlands and Denmark. Bike-sharing schemes, therefore, seem to be most relevant where bicycle ownership is not (yet) peaking (European Commission 2020).

The sector has been affected by the COVID-19 pandemic. Interestingly, recent research (a case study about Budapest in Hungary, for the limited period of March 2020) shows that bike-sharing became more popular due to rapid virus containment measures, while other shared mobility systems saw a lower-than-average decrease. The restrictions to people's mobility due to the pandemic caused, in fact, the lowest decrease of every mean of transport for cycling and bike-sharing in particular (23 and 2\%, respectively) (Bucsky 2020).

\section{Electric Scooter Sharing: A New-Born Means of Shared Mobility}

Similar to what happened in 2018 across the United States, within the past two years, a wave of electric scooter (e-scooter) operators has emerged in European cities. As of March 2020, Paris and Berlin appear to be the hub of e-scooter sharing in Europe, followed by Madrid and Stockholm. At the end of 2019, e-scooter sharing in Europe was available 
in 112 cities (Mobility Foresights 2020). The rapid explosion of companies offering electric scooters in Europe presumably took advantage of a reluctance of people to use public transport during the COVID-19 pandemic, when, in fact, almost ' $93 \%$ of the new riders were turned into regular riders, i.e., more than four rides per week, which is a greater conversion than pre-COVID times' (Mobility Foresights 2020). Due to the increased demand for sustainable transport, many cities promoted e-scooters by both investing in cities' infrastructures (e.g., renovating bicycle paths and/or increasing their length) and in terms of monetary subsidies provided by the government (e.g., subsidies or tax discounts for the purchase of bikes and/or e-scooters).

The increased use and availability of e-scooters in European cities brings opportunities for sustainable transport, but at the same time, the cycling infrastructure needs significant improvement in order to accommodate both bicycles and e-scooters; adequate parking areas are necessary to provide a safer environment for e-scooter use and, at a more general level, the e-scooter invasion on the streets imposes a series of challenges for those managing the public space. As a consequence, a series of regulation challenges have emerged. These are mainly related to the following topics: (i) the spaces where e-scooters can be used (e.g., roads, bike lanes, pavements, pedestrian areas); (ii) their compliance with safety rules (e.g., helmet, lights and turn signals); (iii) age requirements for their users; (iv) the need to re-establish local government competencies in micro-mobility management; and (v) training requirements (e.g., driving licence) (Eltis 2020).

\section{Conflicts and Tensions Around Shared Mobility Uses}

This section presents the challenges that stem from shared mobility experiences identified within the COST Action From Sharing to Caring: Examining Socio-Technical Aspects of the Collaborative Economy gathered from twenty-six country reports on the main trends in the sharing economy regulation and practices by 2019 (Klimczuk et al. 2021) and 
twenty-eight short stories (Sharing and Caring 2020) that presented shared mobility practices from all over Europe in a concise format.

Two main types of challenge, one at the micro-level and another at the macro-level, have been uncovered by the meta-analysis of the country reports and short stories with regard to the shared mobility ecosystem in Europe. At the micro-level, conflicts derived from the uses of sharing mobility schemes are referring to bike-sharing or e-scooter sharing and ride-sourcing (platforms to book a ride/taxi), while at the macro level, inadequate regulations are the source of tensions linked either directly or indirectly to the collaborative economy in general, and to the shared mobility in particular. However, tensions at both levels stem from two questions: (1) who has the right of way, i.e., 'who is the dominant or preferential user of public spaces - including roads, streets, pavements, and parking areas (motor vehicles vs micro-mobility, i.e., passengers, cyclists, or e-scooters)?' and (2) 'how are responsibilities allocated in terms of liability, taxation, and social contribution?'.

The micro-level conflicts emerge due to the rapid growth of bike and e-scooter sharing schemes in a general situation where dockless vehicles are left disorderly on the sidewalks. This exasperates locals in many ways across Europe, from Lisbon, where an urgent need for more thorough legislation is requested by the public (Bettega et al. 2021) through Prague, where these businesses triggered a number of conflicts in connection to issues ranging from parking and safety to legislation, taxation and liability issues (Munzarova 2019), to Oslo, where e-scooters generated particular concerns for the safety of the blind pedestrians and also for the limitations of e-scooter use in winter (Halvorsen et al. 2021).

The conflicts triggered by the new taxi service platforms, such as Uber, Cabify, Taxify (Bolt) and others, are related to the revendications of unfair competition between these new services and the traditional taxi services. In many European cities, taxi drivers' professional associations have organised protests that have led the governments to change transportation regulations. The tensions between collaborative and traditional taxi services followed diverse trends: 
1. 'The unification', which can lead to two different directions: either opening the market for taxi drivers to operate without being subordinated to a central office and requiring taxi licences, such as in Norway and Slovenia, where it is legislated but not applied yet (Halvorsen et al. 2021; Završnik et al. 2021); or making it compulsory for new forms of on-demand ride-services to acquire taxi licenses, as in Poland (Lukasiewicz and Nadolska 2021) and in Finland, where after the transportation deregulation reform, taxi companies and Uber were addressed by the same law and thus can operate under the same conditions (Lanamaki 2018).

2. 'The prohibition of platforms', e.g., in Hungary or Serbia (Simonovits et al. 2021; Ćirić et al. 2021), which often opens a market niche for new players which was left by the prohibited service (e.g., Uber), or, in some cases, had no effective results since the activity is still provided illegally.

3. 'Introducing various forms of specific regulation', even within a country, such as in Germany, where the federal car-sharing law has not yet been fully implemented, while some states and municipalities allowed the designation of public parking areas for car-sharing vehicles (BCS 2019). In 2017, the Spanish government's regulation established the obligation to communicate every transport route that a platform provides, and in 2018, limited their services to interurban routes. Different autonomous regions applied specific restrictions to the use of P2P transport platforms, for instance, the Balearic Islands and Catalonia, in 2019, limiting these services to 'a minimum period of 15 minutes to contract the transportation services' (Garcia-Teruel 2021). In Portugal, in 2018, the new law regulated Uber and similar services by imposing three conditions: drivers must hold driving licences for at least three years and are required to obtain a certificate of a driver of a vehicle operating through digital platforms; cars must be no older than seven years (Bettega et al. 2021).

4. 'Adaptation of the service providers' either by the new or the old actor in the specific market is another way to relieve the tension. In Italy, for example, after being banned for its standard service, Uber withdrew the service for which it had become famous (private drivers with no taxi licence) in favour of its business-class services (Uber Black 
and Uber Lux), which recruits only licenced drivers. The new strategy involves adaptation to local regulations, and cooperation with other market actors, offering them a scheme that increases their income by optimising bookings and working times (Valerio et al. 2021). On the contrary, in Iceland, the traditional taxi company had to adapt to the new situation when their monopoly was abolished by the state due to the increasing demand, which the one and only official taxi company was unable to meet. As new service providers entered the market, the taxi company had to adapt by using a digital platform similar to Uber as an alternative to the traditional phone-based call system (Karlsson 2019).

In some cities, the tensions between new and traditional taxi service providers eventually led to protests and civil conflicts, including physical violence incidents between taxi drivers and platform drivers, and sometimes even with their customers, for example, in Hungary or Portugal (Bettega et al. 2021; Simonovits et al. 2021). Tensions on similar grounds also emerged in some German federal states or municipalities where taxi drivers' associations have tried to stall the expansion of such services both through the courts and on the streets, organising public protests against the new ride-sharing services, driven by the assumption that these new providers with lower rates could be cross-subsidised across locations, marginalising fixed-rate (and more regulated) local services, that work on a traditional, established business model (Zehle et al. 2021).

The macro-level issues around shared mobility derived from inadequate legal frameworks existing in many countries (e.g., in Albania, Bulgaria, Czech Republic, France, Georgia, Hungary, Italy or Lithuania, among others, see Klimczuk et al. 2021), which directly or indirectly affect both shared mobility providers and users. One typical issue for the lack of proper regulation is the vulnerable situation of the platform workers in ride-sharing services. The weak labour market position of the platform workers, their unclear rights and obligations are open issues in some countries, such as Bulgaria or Hungary (Baltova and Vutsova 2021; Simonovits et al. 2021). Closely connected to the field of informal and undeclared work, these can have negative effects at micro and macro levels: it is disadvantageous at the micro-level for the platform workers 
due to insecurity and long-term losses (e.g., unemployment benefit, pension), although it might be beneficial on the short run due to tax and social security contributions avoidance.

On the other hand, the possible macro-level losses derive from the unregulated sharing economy sector burdens on the economy and society. The example from the Czech Republic demonstrates how current taxation, social security and health insurance regulations and visa obligations can be breached by ride-sharing companies to employ thirdcountry nationals. Drivers from the former Soviet Union countries were recruited, via online ads in Russian, to come to Prague on a tourist visa and work as drivers in ride-hailing companies (Tetrevova 2021). France deals with two main issues regarding regulations affecting platforms and platform workers, but mainly from the macro-economic aspect (Barbezieux and Herody 2019): one is to ensure the tax contribution of platforms to national/local budgets, while the other is to clarify the position of tax authorities on the distinction between income and cost-sharing and that of the social administration on the notion of professional activity (Lewkowicz 2021). The latter issue is embedded into the general discussion in France on the ambiguous status of workers in the collaborative economy who are considered 'legally independent' but 'economically dependent' (Institut Montaigne 2019).

\section{Shared Mobility in the Time of COVID-19}

Before the pandemic, shared mobility, vehicle sharing schemes and trip sharing gained in popularity. However, the situation has been changing since the World Health Organization (WHO) officially declared the outbreak of the COVID-19 virus in March 2020. The general idea during the crisis has been to significantly reduce movement, as well as keep a social distance, but these indications do not match the sharing mobility model, especially in the cases of car and trip sharing schemes. As a consequence, a significant drop in the use of shared modes of transportation has been observed, and real-time ride-sharing and the industry has very quickly lost both passengers and profits (Andersson et al. 2020). According to Andersson et al. (2020), only 5-8\% of respondents think 
that car-sharing, ride-sharing, or shared micro-mobility are safe from a health standpoint. Subsequently, 7\% feel public transportation is safe, and $81 \%$ consider private vehicles safe. Concerning those safety issues, people have changed their mobility patterns greatly. Furthermore, ridehailing companies in multiple geographies have experienced a $60-70 \%$ decline in passengers during the COVID-19 crisis.

Supposedly, the post-lockdown world will impose significant challenges in developing shared modes usage. Mobility solutions will have to tackle critical aspects, in particular, ensuring safe and healthy commuting modes. In this scenario, cycling and walking might be favoured as they make it easier to maintain physical distance. Additionally, by strengthening multi-modal and complementary integration with public transport, shared mobility service markets could be significantly revived.

So far, many Europe-wide local authorities have begun to encourage this trend well before the outbreak of the pandemic (Lozzi et al. 2020). In fact, these services require careful integration into the local transport system, thus avoiding risks such as the increase of unnecessary travel. Given the need for more flexible public transport, shared vehicles, such as electric cars, bicycles, e-scooters, can become part of the offer, providing more integrated transport solutions.

An efficient and more sustainable transportation system needs, in fact, increasing the diversity of transportation means (Litman 2021) while diminishing the use and circulation of vehicles, as well as moving towards more efficient modes of transportation such as public transport, walking, cycling and shared modes. Although private cars often represent users' preferred options for reasons of flexibility and comfort, a main social and environmental goal is to reduce traffic, congestion and air emissions while improving people's health and well-being. Shared mobility, promoting the use of fewer vehicles to move the same number of users, can contribute to reaching these goals. 


\section{Summary}

Shared mobility systems have become a common feature of the modern urban landscape in many European cities (Shaheen et al. 2015), providing residents and visitors with a new mode of sustainable transportation. Shared systems have gained popularity, especially among young generations, while this is not always true for older people or disadvantaged groups for whom technological issues, accessibility and geographical locations can represent significant barriers to the access and/or use of such services. Indeed, usage of smartphone apps aggregating information about real-time travel, options, in addition to optimisation of routes for travellers, have occurred as an important component of shared mobility but can constitute exclusion factors for 'some' potential users.

Recently, holistic transport system approaches for providing more integrated transport solutions, in the framework of the sharing economy, namely the Mobility as a Service (MaaS) concept, have been developed. The most important of these, as in collaborative consumption, are based on services that promote the shift away from personally owned modes of transportation, especially cars.

Nevertheless, unbalanced and rapid socio-economic growth has resulted in a multitude of effects on society, as well as the environmentincluding traffic congestion, pollution and health-related issues-which in the absence of a radical shift towards more sustainable (and possibly shared) means of transportation, might worsen even further in the immediate future.

In this scenario, shared mobility might play a key role in a transition towards a more sustainable European mobility system. However, sustainability in the transport sector is hard to achieve, as a variety of stakeholders are involved. The shortage of resources, the unwillingness to share benefits and opposite interests can lead to conflicts. Also, the appearance of new services such as electric scooters sharing-adding pressure on the existing, limited infrastructure and in the absence of clear regulations - can generate additional frictions.

The assumptions of sustainable development depicted in Agenda 2030 are aimed at prosperity and attention for all stakeholders. Thus, all 
parts involved in the process of creating new business models in shared mobility should be considered and possibly satisfied.

The COVID-19 pandemic exacerbated some issues and limitations to the achievement of sustainable development goals connected to the transport sector and mobility in particular, and because of the many restrictions introduced in order to limit the spread of the diseases, a factual shift away from personally owned modes of transportation and towards mobility provided as a service might be compromised. The general indication to significantly reduce movements as well as keep social distance, in particular, does not match the assumptions of sharing mobility, especially in the case of car-sharing, trip sharing schemes. That is why there has been a big drop in using shared modes of transportation, real-time ride-sharing has significantly diminished, and the industry has very quickly lost both passengers and profits (Andersson et al. 2020).

The dynamic and uncertainty of the current situation indicate, therefore, a further transition. Notwithstanding, by strengthening multimodal and complementary integration with public transport, shared mobility service markets could be significantly revived. The main goal is to reduce the production of pollution and traffic congestion while increasing health and well-being. Sharing mobility, using fewer vehicles to move the same number of users can equally contribute to reaching these goals.

\section{References}

Andersson, Lennart, Andreas Gläfke, Timo Möller, and Tobias Schneiderbauer. 2020. Why Shared Mobility Is Poised to Make a Comeback after the Crisis. Atlanta: McKinsey \& Co. Accessed November 15, 2020. https://www.mck insey.com/ /media/McKinsey/Industries/AutomotiveandAssembly/OurIns ights/Whysharedmobilityispoisedtomakeacomebackafterthecrisis/Why-sha red-mobility-is-poised-to-make-a-comeback-after-the-crisis-vF.pdf?should Index $=$ false .

Articonf. 2020. 'How COVID-19 Affects Carsharing? Ridesharing Business Post-Pandemic.' Accessed November 15, 2020. https://articonf.eu/howcovid-19-affects-carsharing/. 
Baltova, Stela, and Albena Vutsova. 2021. 'Setting the Stage of the Sharing Economy: The Case of Bulgaria.' In The Collaborative Economy in Action: European Perspectives, edited by Andrzej Klimczuk, Vida Česnuitytè, and Gabriela Avram. Limerick, Ireland: University of Limerick.

Barbezieux, Philippe, and Camille Herody. 2019. 'Rapport Au Premier Ministre Sur l'économie Collaborative. Mission Confiée à Pascal Terrasse Député de l'Ardeche.' Hôtel de Matignon. Accessed March 15, 2021. https://www.gouvernement.fr/sites/default/files/document/document/2016/ 02/08.02.2016_rapport_au_premier_ministre_sur_leconomie_collabora tive.pdf.

BCS (Bundesverband CarSharing). 2019. CarSharing in Deutschland Jahresbericht [Annual Report] 2018/19. Berlin: Bundesverband CarSharing e.V.

Bettega, Mela, Raul Masu, and Alves Pereira Diogo, Vera Lúcia. 2021. 'Collaborative Economy in Portugal: The Recent Evolution.' In The Collaborative Economy in Action: European Perspectives, edited by Andrzej Klimczuk, Vida Česnuityte, and Gabriela Avram. Limerick, Ireland: University of Limerick. Bucsky, Péter. 2020. 'Modal Share Changes Due to COVID-19: The Case of Budapest.' Transportation Research Interdisciplinary Perspectives vol. 8: 100141. Accessed May 10, 2021. https://doi.org/10.1016/j.trip.2020. 100141.

Ćirić, Maja, Svetlana Ignjatijević, Aleksandra Fedajev, Marija Panić, Dejan Sekulić, Tanja Stanišić, Miljan Leković, and Sanela Arsić. 2021. 'Serbia: Sharing Economy as a New Market Trend and Business Model.' In The Collaborative Economy in Action: European Perspectives, edited by Andrzej Klimczuk, Vida Česnuitytė, and Gabriela Avram. Limerick, Ireland: University of Limerick.

CIVITAS (Cleaner and Better Transport in Cities). 2016. Smart Choices for Cities. Cities towards Mobility 2.0: Connect, Share and Go! Porto: CIVITAS Initiative.

Crozet, Yves, Georgina Santos, and Jean Coldefy. 2019. Shared Mobility, MaaS and the Regulatory Challenges of Urban Mobility. Brussels: Centre on Regulation in Europe CERRE. Accessed March 8, 2021. https://cerre.eu/wp-con tent/uploads/2020/07/190827_CERRE_MaaS_FinalReport.pdf.

Elkington, John Brett. 1999. Cannibals with Forks: The Triple Bottom Line of Sustainability. New Society Publishers. Oxford: Capstone Publishing.https:// doi.org/10.1002/tqem.3310080106. 
Eltis. 2020. 'Overview of Policy Relating to E-Scooters in European Countries.' 2020. https://www.eltis.org/resources/case-studies/overview-policy-rel ating-e-scooters-european-countries.

European Commission. 2016. 'A European Agenda for the Collaborative Economy.' $\operatorname{COM}(2016) 356$ final. Communication from the Commission to the European Parliament, the European Economic and Social Committee of the Regions. Accessed November 15, 2020. Brussels: European Commission. https://ec.europa.eu/docsroom/documents/16881/attach ments/2/translations/en/renditions/pdf.

European Commission. 2019. Transport in the European Union Current Trends and Issues. Brussels: European Commission, Directorate-General Mobility and Transport. Accessed November 15, 2020. https://ec.europa.eu/transp ort/sites/transport/files/2019-transport-in-the-eu-current-trends-and-issues. pdf.

European Commission. 2020. 'Walking and Cycling as Transport Modes I Mobility and Transport.' Accessed November 15, 2020. https://ec.europa. eu/transport/road_safety/specialist/knowledge/pedestrians/pedestrians_and_ cyclists_unprotected_road_users/walking_and_cycling_as_transport_mod es_en.

Eurostat. 2020a. Eurostat Regional Yearbook. Luxembourg: Publications Office of the European Union. Accessed March 8, 2021. https://doi.org/10.2785/ 98733.

Eurostat. 2020b. 'Transport Statistics at Regional Level.' Statistics Explained. Accessed March 8, 2021. https://ec.europa.eu/eurostat/statisticsexplained/.

Freeman, R. Edward. 1984. Strategic Management: A Stakeholder Approach. Boston: Pitman.

Freeman, R. Edward, Jeffrey S. Harrison, Andrew C. Wicks, Bidhan L. Parmar, and Simon de Colle. 2010. Stakeholder Theory: The State of the Art. Cambridge: Cambridge University Press.

Garcia-Teruel, Rosa M. 2021. 'An Introduction to the Collaborative Economy in Spain.' In The Collaborative Economy in Action: European Perspectives, edited by Andrzej Klimczuk, Vida Česnuityte, and Gabriela Avram. Limerick, Ireland: University of Limerick.

Halvorsen, Trond, Christoph Lutz, and Johan Barstad. 2021. 'The Sharing Economy in Norway: Emerging Trends and Debates.' In The Collaborative Economy in Action: European Perspectives, edited by Andrzej Klimczuk, Vida Česnuityte, and Gabriela Avram. Limerick, Ireland: University of Limerick. 
Institut Montaigne. 2019. 'Travailleurs Des Plateformes: Liberté Oui, Protection Aussi.' Paris: Institut Montaigne. Accessed March 8, 2021. https:// www.institutmontaigne.org/ressources/pdfs/publications/travailleurs-des-pla teformes-liberte-oui-protection-aussi-rapport.pdf.

Karlsson, Emil. 2019. 'Transforming the 'Uber-Model' into a Cooperative.' COST Action Sharing and Caring, Short Stories. Accessed March 8, 2021. http://sharingandcaring.eu/case-study/transforming-uber-modelcooperative.

Klimczuk, Andrzej, Vida Česnuitytè, and Gabriela Avram, eds. 2021. The Collaborative Economy in Action: European Perspectives. Limerick, Ireland: University of Limerick.

Lanamaki, Arto. 2018. 'Uber in Helsinki, Finland, after the Deregulation in July 2018.' COST Action Sharing and Caring, Short Stories. Accessed March 8, 2021. http://sharingandcaring.eu/case-study/uber-hel sinki-finland-after-deregulation-july-2018.

Lewkowicz, Myriam. 2021. 'France: An Ecosystem Favourable to the Development of the Sharing Economy.' In The Collaborative Economy in Action: European Perspectives, edited by Andrzej Klimczuk, Vida Česnuityte, and Gabriela Avram. Limerick, Ireland: University of Limerick.

Litman, Todd. 2021. 'Developing Indicators for Sustainable and Livable Transport Planning.' Victoria Transport Policy Institute. Accessed March 8, 2021. http://www.vtpi.org/wellmeas.pdf.

Lozzi, Giacomo, Maria Rodrigues, Edoardo Marcucci, Tharsis Teoh, Valerio Gatta, and Valerio Pacelli. 2020. Research for TRAN Committee: COVID19 and Urban Mobility: Impacts and Perspectives. Brussels: European Parliament, Policy Department for Structural and Cohesion Policies. Accessed November 15, 2020. https://www.europarl.europa.eu/thinktank/ en/document.html?reference=IPOL_IDA(2020)652213.

Lukasiewicz, Agnieszka, and Aleksandra Nadolska. 2021. 'Poland: Country Report on the Sharing Economy.' In The Collaborative Economy in Action: European Perspectives, edited by Andrzej Klimczuk, Vida Česnuitytè, and Gabriela Avram. Limerick, Ireland: University of Limerick.

Machado, Cláudia A. Soares, Nicolas Patrick Marie de Salles Hue, Fernando Tobal Berssaneti, and José Alberto Quintanilha. 2018. 'An Overview of Shared Mobility.' Sustainability (Switzerland) 10 (12): 1-21. https://doi.org/ 10.3390/su10124342.

MarketsandMarkets Research Private Ltd. 2020 'COVID-19 Impact on Ride Sharing Market by Service Type, Data Service, and Region: Forecast to 
2021.' Accessed November 15, 2020. https:/www.marketsandmarkets.com/ Market-Reports/covid-19-impact-on-ride-sharing-market-15098676.html. Meddin, Russell, Paul DeMaio, Oliver O’Brien, Renata Rabello, Chumin Yu, Jess Seamon, Thiago Benicchio, Deng Han, and Jacob Mason. 2020. 'The Meddin Bike-Sharing World Map.' Accessed November 15, 2020. http:// bikesharingworldmap.com/.

Mitrović Dankulov, Marija, Maria Del Mar Alonso-Almeida, Fariya Sharmeen, and Agnieszka Lukasiewicz. 2020. 'Social Networks Theory: Definitions and Practice.' In Digital Social Networks and Travel Behaviour in Urban Environments, edited by Pnina O. Plaut and Dalit Shach-Pinsly, 7-26. Milton Park, Abingdon, Oxon; New York, NY: Routledge. https://doi.org/10.4324/978 0429488719 .

Mobility Foresights. 2020. 'E Scooter Sharing Market 2019-2024.' Accessed December 15, 2020. https://mobilityforesights.com/product/scooter-sha ring-market-report/.

Movmi. 2019. 'Car-Sharing Industry: Carsharing Market \& Growth 2019.' 2019. Accessed December 15, 2020. https://movmi.net/carsharing-marketgrowth-2019/.

Munzarova, Simona. 2019. 'Electric Scooter Sharing: LIME in the Czech Republic.' COST Action Sharing and Caring, Short Stories. 2019. Accessed December 15, 2020. http://sharingandcaring.eu/case-study/electric-scootersharing-lime-czech-republic.

Rodenbach, Johannes, Jeffrey Mathis, Andrea Chicco, Marco Diana, Johannes Rodenbach Marco Diana, Peter Wells, and Stefano Beccaria. 2018. 'Car Sharing in Europe: A Multidimensional Classification and Inventory.' Deliverable D2.1, Research and Innovation action H2020-MG-2016-2017, Shared Mobility Opportunities and Challenges foR European Cities. Torino. Accessed March 8, 2021. http://stars-h2020.eu/wp-content/uploads/2019/ 06/STARS-D2.1.pdf.

Santos, Georgina. 2018. 'Sustainability and Shared Mobility Models.' Sustainability 10 (3194): 1-13. https://doi.org/10.3390/su10093194.

Schiller, Thomas, Julia Scheidl, and Thomas Pottebaum. 2017. 'Car Sharing in Europe: Business Models, National Variations and Upcoming Disruptions.' Monitor Deloitte, no. 6: 1-8. Accessed March 15, 2021. https://www2. deloitte.com/content/dam/Deloitte/de/Documents/consumer-industrial-pro ducts/CIP-Automotive-Car-Sharing-in-Europe.pdf.

Shaheen, Susan, Nelson Chan, Apaar Bansal, and Adam Cohen. 2015. Shared Mobility: A Sustainability \& Technologies Workshop: Definitions, Industry 
Developments, and Early Understanding. Berkley, CA: University of California. Accessed March 15, 2021. https://escholarship.org/content/qt2f61 q30s/qt2f61q30s.pdf.

Sharing and Caring COST Action CA16121. 2020. 'Short Stories.' Accessed November 15, 2020. http://sharingandcaring.eu/short-stories.

Simonovits, Bori, Anikó Bernát, and Bálint Balázs. 2021. 'The Fragile Landscape of the Sharing Economy in Hungary.' In The Collaborative Economy in Action: European Perspectives, edited by Andrzej Klimczuk, Vida Česnuitytè, and Gabriela Avram. Limerick, Ireland: University of Limerick.

Standing, Craig, Susan Standing, and Sharon Biermann. 2019. 'The Implications of the Sharing Economy Fortransport.' Transport Reviews 39 (2): 226-42. https://doi.org/10.1080/01441647.2018.1450307.

Tetrevova, Libena. 2021. 'The Sharing Economy in Practice in the Czech Republic: A Small Post-Communist Economy.' In The Collaborative Economy in Action: European Perspectives, edited by Andrzej Klimczuk, Vida Česnuitytè, and Gabriela Avram. Limerick, Ireland: University of Limerick. United Nations. 2016. Mobilising Sustainable Transport for Development. Analysis and Policy Recommendations from the United Nations Secretary-General's High-Level Advisory Group on Sustainable Transport. New York, NY: United Nations. https://doi.org/10.18356/2c1884f4-en.

UNPF (United Nations Population Fund). 2015. Transforming Our World: The 2030 Agenda for Sustainable Development. A/RES/70/1. New York: United Nations Population Fund. Accessed November 15, 2020. https://www.unfpa.org/sites/default/files/resource-pdf/Resolution_A_ RES_70_1_EN.pdf.

Valerio, Stefano, Monica Postiglione, Venere Stefania Sanna, Chiara Bassetti, and Giulia Priora. 2021. 'Italian Style: Legislative Developments in Accommodation, Mobility, Food, Delivery, and Transport in Italy's Collaborative and Sharing Economy.' In The Collaborative Economy in Action: European Perspectives, edited by Andrzej Klimczuk, Vida Česnuitytè, and Gabriela Avram. Limerick, Ireland: University of Limerick. Forthcoming.

Wikipedia. 2020. 'List of Bicycle-Sharing Systems.' Accessed November 15, 2020. https://en.wikipedia.org/wiki/List_of_bicycle-sharing_systems.

World Commission on Environment and Development. 1987. Our Common Future. New York: United Nations. Accessed February 7, 2021. https://sustainabledevelopment.un.org/content/documents/5987ourcommon-future.pdf. 
Završnik, Aleš, Katja Simončič, Manja Kitek Kuzman, and Tomaž Kušar. 2021. 'A Snapshot of Slovenia's Collaborative Economy.' In The Collaborative Economy in Action: European Perspectives, edited by Andrzej Klimczuk, Vida Česnuityte, and Gabriela Avram. Limerick, Ireland: University of Limerick. Zehle, Soenke, Hannes Käfer, Julia Hartnik, and Michael Schmitz. 2021. 'Germany: Co-creating Cooperative and Sharing Economies.' In The Collaborative Economy in Action: European Perspectives, edited by Andrzej Klimczuk, Vida Česnuityte, and Gabriela Avram. Limerick, Ireland: University of Limerick.

\section{Suggested Readings}

Cohen, Boyd, and Jan Kietzmann. 2014. 'Ride On! Mobility Business Models for the Sharing Economy.' Organization \& Environment 27 (3): 279-296.

Nail, Thomas. 2018. The Ontology of Motion. Edinburgh: Edinburgh University Press. https://doi.org/10.1215/10418385-438298.

Sassen, Saskia. 2014. Expulsions: Brutality and Complexity in the Global Economy. Cambridge, MA: Harvard University Press.

Vaughan, Robert, and Raphael Daverio. 2017. Assessing the Size and Presence of the Collaborative Economy in Europe. Brussels: European Commission, Directorate-General for Internal Market, Industry, Entrepreneurship and SMEs. https://doi.org/10.2873/971404.

\section{Relevant Websites}

CIVITAS (Cleaner and Better Transport in Cities): https://civitas-initiative.eu. European Commission webpage about the urban mobility issues. https://ec.eur opa.eu/transport/themes/urban/urban_mobility_en.

The European Cyclists' Federation (ECF): https://ecf.com/topics/bike-sharing. World Transit Research: https://www.worldtransitresearch.info. 
Open Access This chapter is licensed under the terms of the Creative Commons Attribution 4.0 International License (http://creativecommons.org/ licenses/by/4.0/), which permits use, sharing, adaptation, distribution and reproduction in any medium or format, as long as you give appropriate credit to the original author(s) and the source, provide a link to the Creative Commons license and indicate if changes were made.

The images or other third party material in this chapter are included in the chapter's Creative Commons license, unless indicated otherwise in a credit line to the material. If material is not included in the chapter's Creative Commons license and your intended use is not permitted by statutory regulation or exceeds the permitted use, you will need to obtain permission directly from the copyright holder.

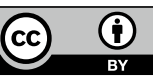

